\title{
THERMODYNAMIC STUDY OF NOx AND SO FORMATION AND POSSIBLE REDUCTION DURING Pb WASTE RECYCLING
}

\author{
Silvia Demčáková*, Hedviga Horváthová* \\ * Technical University of Košice, Faculty of Materials, Metallurgy and Recycling, Institute of Recycling \\ Technologies, Slovakia
}

corresponding author: Silvia Demčáková, e-mail: silvia.demcakova@tuke.sk

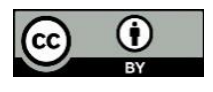

This work is licensed under a

$\underline{\text { Creative Commons Attribution } 4.0}$

International License
Professional paper

Received: May 13 ${ }^{\text {th }}, 2020$

Accepted: June 29 $9^{\text {th }}, 2020$

HAE- 1962

https://doi.org/10.33765/thate.11.3.2

\begin{abstract}
With the increasing demand for electricity due to the increasing economic boom, there is an excessive production of emissions that natural processes cannot cope with. Fortunately, there are various technological solutions for capturing harmful substances from produced emissions. However, the European Union aims to prevent the formation of emissions in the process of industrial production itself. In order to achieve this, it is necessary to reconcile the interests of individual European Union member states by the implementation of regulations into laws, to monitor short-term and long-term changes in air quality, and also to put into practice increasingly effective methods of capturing emissions from the air. This paper offers an example of thermodynamic calculation of quantities by appropriate software in the process of recycling waste from the metallurgical industry and possibilities of technological improvement in emission reduction.
\end{abstract}

Keywords: air quality, $\mathrm{SO}_{2}$ emissions, $\mathrm{NO}_{x}$ emissions, lead accumulators, $H S C$ chemistry 6.1

\section{INTRODUCTION}

The annual increase in energy demand and consumption forces power plants to produce more and more electricity and heat. Consequently, it also increases the production of more polluting gases, especially in urban areas. In the production of thermal energy, the combustion of fossil fuels produces harmful gaseous chemical compounds, such as carbon dioxide $\left(\mathrm{CO}_{2}\right)$, sulphur dioxide $\left(\mathrm{SO}_{2}\right)$, nitrogen oxides $\left(\mathrm{NO}_{\mathrm{x}}\right)$, unburnt hydrocarbons (UHCs), as well as solid particles. Road transport also accounts for a significant proportion, accounting for almost $60 \%$ of emissions in the European Union (EU).

$\mathrm{SO}_{2}$ and $\mathrm{NO}_{\mathrm{x}}$ belong to the gaseous pollutants produced by the combustion of fossil fuels. With secondary pollutants derived from $\mathrm{SO}_{2}$ and $\mathrm{NO}_{\mathrm{x}}$, such as sulphuric acid $\left(\mathrm{H}_{2} \mathrm{SO}_{4}\right)$, nitric acid $\left(\mathrm{HNO}_{3}\right)$, they are harmful to humans and the natural environment [1]. Acid rains containing weak sulphuric and nitric acids enter the soil, leaching out elements such as calcium, manganese, sodium, potassium, 
which significantly deteriorates its quality and consequently the quality of watercourses. As a result of insufficient water supply, trees in forests dry up and die. The adverse effect of acid rains is also reflected in buildings, erosion of statues and corrosion of metal structures. That is why the issue of $\mathrm{SO}_{2}$ and $\mathrm{NO}_{\mathrm{x}}$ emissions is still very topical - one of the critical problems in pollution control and air quality management.

The European Pollutant Release and Transfer Register (E-PRTR) covers the 27 EU member states as well as Iceland, Lichtenstein, Norway, Serbia, and Switzerland. The EPRTR contains data reported from approximately 30,000 industrial installations per year, 65,000 different economic activities, including nine industrial sectors: energy, metal production and processing, metallurgical and chemical industries, waste and wastewater management, paper and wood-processing industries, meat and livestock production, agriculture and other activities [2]. The data from the register is processed into an interactive map of European countries in Figure 1, which provides information on air quality based on the European Air Quality Index. The European Air Quality Index shows the status of short-term air quality at each of over 2,000 monitoring stations across Europe. The index consists of an interactive map of local air quality by measuring stations based on five key pollutants that harm human health and the environment: particulate matter $\left(\mathrm{PM}_{2.5}\right.$ and $\left.\mathrm{PM}_{10}\right)$, ground-level ozone $\left(\mathrm{O}_{3}\right)$, nitrogen dioxide $\left(\mathrm{NO}_{2}\right)$ and sulphur dioxide $\left(\mathrm{SO}_{2}\right)$. European Union legislation sets air quality standards for short (hourly/daily) and long (annual) periods. Therefore, the index does not reflect the long-term (annual) air quality situation, which may vary significantly [3].

Circles on the map represent the locations of air quality monitoring stations. Based on data from the interactive map, air quality in most of Europe is good. Less satisfactory results are from the southern part of Europe, where air quality is moderate to poor. Good air quality is achieved when the concentration of the five measured pollutants, such as particle matters $\mathrm{PM}_{2.5}$ and $\mathrm{PM}_{10}$, and $\mathrm{NO}_{2}, \mathrm{O}_{3}$ and $\mathrm{SO}_{2}$ are ranging between 0 to $10,20,40,50,100$ $\mu \mathrm{g} / \mathrm{m} 3$, respectively [3].

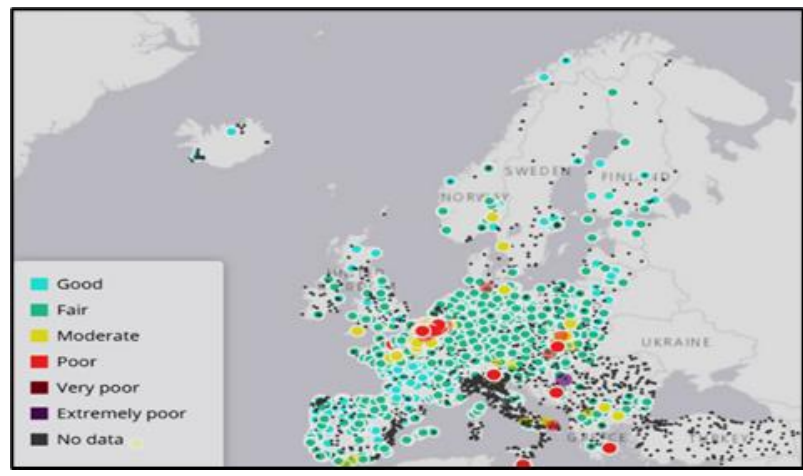

Figure 1. Current air quality (20 April 2020, 12:00 h) across all cities based on the European Air Quality Index [3]

The Copernicus Atmosphere Monitoring Service (CAMS) provides continuous information on atmospheric composition values in Europe and worldwide [4]. The service analyses the current situation forecasts for the next days, and also shows a look back into the past on air quality and atmospheric composition, ozone and UV radiation, emissions, climate change and solar radiation. The output is, for example, an interactive map of changes in the concentration of ozone, nitrogen and sulphur oxides, carbon monoxide, particle matters $\mathrm{PM}_{10}$ and $\mathrm{PM}_{2.5}$ or secondary inorganic aerosols on the surface of the earth or $500-3000 \mathrm{~m}$ above the surface in $\mu \mathrm{g} / \mathrm{m}^{3}$. The information about pollution could be viewed in time scale 24 hours before real-time and provides the air quality forecast for the next 96 hours. The output can be also a report on the air condition, which can be generated after registration on the service page with feedback for 30 days. From Figure 2 it is evident that in 2017 the most greenhouse gases in the European Union were produced by Luxembourg (20 t/person/year) and the least by Lichtenstein (5.1 t/person/year) [5].

$\mathrm{NO}_{\mathrm{x}}$ and $\mathrm{SO}_{2}$ emissions can potentially occur during the hydrometallurgical processing of raw materials/intermediates to obtain useful metals. These may be intermediate products resulting from the processing of various metalcontaining ores, e.g., sulphide concentrates of metals [6]. They also occur, for example, in 
the recycling of electrical and electronic waste or in the recycling of lead-acid batteries, where leaching of stone and slag (lead melting intermediates) in nitric and sulfuric acid produces $\mathrm{NO}_{\mathrm{x}}$ or $\mathrm{SO}_{2}$ emissions [6, 7].

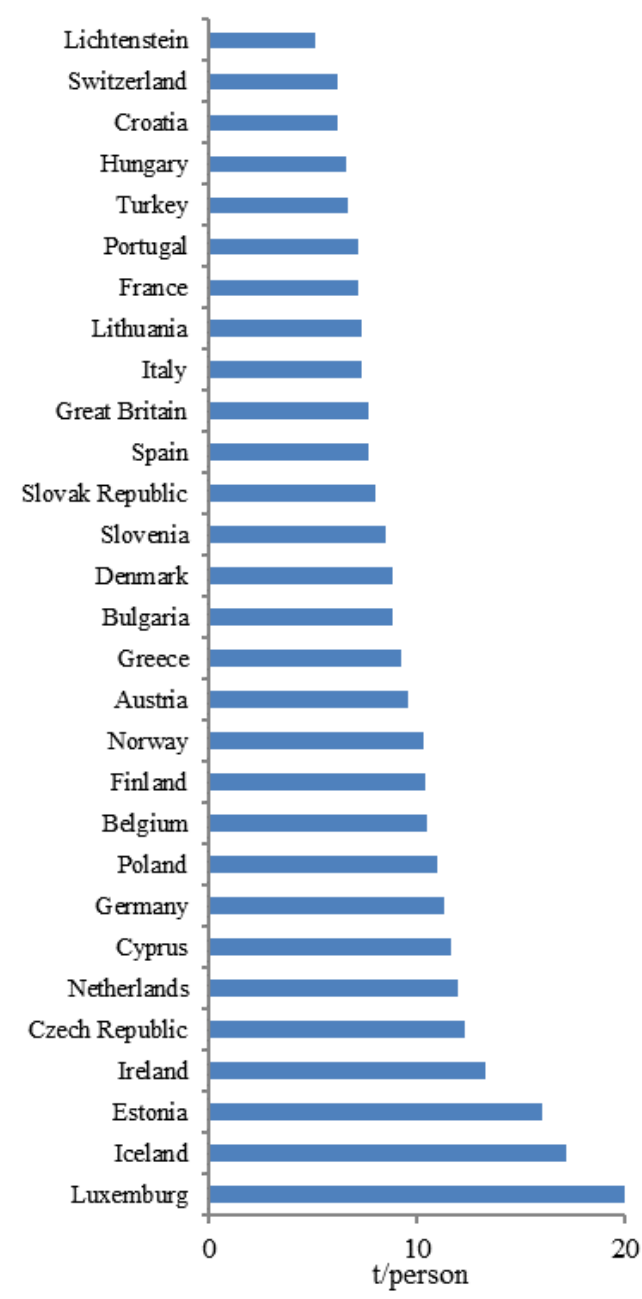

Figure 2. Greenhouse gas emissions in tonnes per capita for 2017, according to the European Environment Agency [5]

The lead smelting slag and matte from $\mathrm{Pb}$ batteries contain $\mathrm{Pb}$ in metallic form, as well as in the form of galena $(\mathrm{PbS})$. Iron is present in the stone as $\mathrm{FeS}$ (troilite) and $\mathrm{FeO}$ (wüstite). The slag contains $\mathrm{Fe}_{2} \mathrm{SiO}_{4}$ phases as well as FeS. In addition to these phases, impurities, such as $\mathrm{Ca}$ and $\mathrm{Si}$ are present in the rock and slag. The authors of the study [6] focused on the selective leaching of $\mathrm{Pb}$ from stone and slag.

The goal of the study in this paper is to describe the thermodynamic conditions of the process of leaching of individual phases of stone and slag containing $\mathrm{Pb}$ by calculating standard Gibbs energies of reactions $\left(\Delta \mathrm{G}^{\circ} \mathrm{T}\right)$, enthalpy change $\left(\Delta \mathrm{H}^{\circ} \mathrm{T}\right)$, entropy of reaction $\left(\Delta \mathrm{S}^{\circ} \mathrm{T}\right)$ and the equilibrium constant $\mathrm{K}\left[\mathrm{mol}^{-1}\right.$ $\left.\mathrm{dm}^{3}\right]$ at different temperatures in the range of $25{ }^{\circ} \mathrm{C}$ to $200{ }^{\circ} \mathrm{C}$. Another objective is to propose a possible way to eliminate emissions emerging during the process.

\section{EXPERIMENTAL}

The chemical reaction equations (1) - (4) describe the leaching of $\mathrm{Pb}$ and $\mathrm{Fe}$ from galena $(\mathrm{PbS})$ and troilite $(\mathrm{FeS})$ in nitric acid. For the given chemical reactions, the values of the change of standard Gibbs energies $\left(\Delta \mathrm{G}^{\circ} \mathrm{T}\right)$, as well as other thermodynamic quantities at temperatures from $25{ }^{\circ} \mathrm{C}$ to $200{ }^{\circ} \mathrm{C}$, were calculated using the HSC Chemistry program (HSC version 6.1) [8], which are summarized in the Tables $1-5$.

\section{RESULTS AND DISCUSSION}

Equations (1) and (2) describe the leaching of lead and iron (from $\mathrm{PbS}, \mathrm{FeS}$ ) in nitric acid, with the formation of $\mathrm{NO}(\mathrm{g})$.

$$
\begin{gathered}
3 \mathrm{PbS}+2 \mathrm{NO}_{3}^{-}(\mathrm{a})+8 \mathrm{H}^{+} \rightarrow 3 \mathrm{~Pb}^{2+}+3 \mathrm{~S}^{0}+ \\
2 \mathrm{NO}(\mathrm{g})+4 \mathrm{H}_{2} \mathrm{O} \\
\mathrm{FeS}+3 \mathrm{NO}_{3}^{-}(\mathrm{a})+5 \mathrm{H}^{+} \rightarrow \mathrm{Fe}^{3+}+\mathrm{HSO}_{4}^{-}+ \\
3 \mathrm{NO}(\mathrm{g})+2 \mathrm{H}_{2} \mathrm{O}
\end{gathered}
$$

Thermodynamic quantities for equations (1) and (2) are shown in Tables 1 and 2.

During the leaching of $\mathrm{FeS}, \mathrm{Fe}^{3+}$ is formed, which acts as an oxidizing agent, thus allowing further leaching of $\mathrm{Pb}$ from galena to form $\mathrm{Fe}^{2+}$ ions (equation (3)).

$$
\mathrm{PbS}+2 \mathrm{Fe}^{3+} \rightarrow \mathrm{Pb}^{2+}+2 \mathrm{Fe}^{2+}+\mathrm{S}^{0}
$$

Thermodynamic quantities for equation (3) are shown in Table 3. 
Table 1. Thermodynamic quantities for equation (1) calculated using the HSC Chemistry program (HSC version 6.1)

\begin{tabular}{|c|c|c|c|c|c|}
\hline $\begin{array}{c}\mathrm{T}, \\
\mathrm{K}\end{array}$ & $\begin{array}{c}\Delta \mathrm{H}^{\circ} \mathrm{T}, \\
\mathrm{kJ}\end{array}$ & $\begin{array}{c}\Delta \mathrm{S}^{\circ} \mathrm{T}, \\
\mathrm{J} \mathrm{K}^{-1}\end{array}$ & $\begin{array}{c}\Delta \mathrm{G}^{\circ} \mathrm{T}, \\
\mathrm{kJ} \mathrm{mol}^{-1}\end{array}$ & $\begin{array}{c}\mathrm{K}, \\
\mathrm{mol}^{-1} \mathrm{dm}^{3}\end{array}$ & $\log (\mathrm{K})$ \\
\hline 298.15 & -125.718 & 142.758 & -168.281 & $3.053 \mathrm{E}+029$ & 29.485 \\
\hline 318.15 & -123.119 & 151.193 & -171.222 & $1.300 \mathrm{E}+028$ & 28.114 \\
\hline 338.15 & -120.498 & 159.185 & -174.326 & $8.526 \mathrm{E}+026$ & 26.931 \\
\hline 358.15 & -117.896 & 166.659 & -177.585 & $7.985 \mathrm{E}+025$ & 25.902 \\
\hline 378.15 & -114.729 & 175.264 & -181.005 & $1.011 \mathrm{E}+025$ & 25.005 \\
\hline 398.15 & -109.540 & 188.628 & -184.642 & $1.682 \mathrm{E}+024$ & 24.226 \\
\hline 418.15 & -106.886 & 195.133 & -188.480 & $3.521 \mathrm{E}+023$ & 23.547 \\
\hline 438.15 & -104.159 & 201.500 & -192.446 & $8.803 \mathrm{E}+022$ & 22.945 \\
\hline 458.15 & -101.509 & 207.415 & -196.537 & $2.567 \mathrm{E}+022$ & 22.409 \\
\hline 473.15 & -125.718 & 142.758 & -168.281 & $3.053 \mathrm{E}+029$ & 29.485 \\
\hline
\end{tabular}

Table 2. Thermodynamic quantities for equation (2) calculated using the HSC Chemistry program (HSC version 6.1)

\begin{tabular}{|c|c|c|c|c|c|}
\hline $\mathrm{T}$, & $\begin{array}{c}\Delta \mathrm{H}^{\circ} \mathrm{T}, \\
\mathrm{kJ}\end{array}$ & $\begin{array}{c}\Delta \mathrm{S}^{\circ} \mathrm{T}, \\
\mathrm{J} \mathrm{K}^{-1}\end{array}$ & $\begin{array}{c}\Delta \mathrm{G}^{\circ} \mathrm{T}, \\
\mathrm{kJ} \mathrm{mol}^{-1}\end{array}$ & $\begin{array}{c}\mathrm{K}, \\
\mathrm{mol}^{-1} \mathrm{dm}^{3}\end{array}$ & $\log (\mathrm{K})$ \\
\hline 298.15 & -515.136 & 125.289 & -552.491 & $6.342 \mathrm{E}+096$ & 96.802 \\
\hline 318.15 & -508.917 & 145.492 & -555.205 & $1.454 \mathrm{E}+091$ & 91.163 \\
\hline 338.15 & -503.383 & 162.372 & -558.289 & $1.766 \mathrm{E}+086$ & 86.247 \\
\hline 358.15 & -498.344 & 176.853 & -561.684 & $8.436 \mathrm{E}+081$ & 81.926 \\
\hline 378.15 & -493.718 & 189.427 & -565.350 & $1.258 \mathrm{E}+078$ & 78.100 \\
\hline 398.15 & -489.477 & 200.361 & -569.250 & $4.877 \mathrm{E}+074$ & 74.688 \\
\hline 418.15 & -487.105 & 206.200 & -573.328 & $4.219 \mathrm{E}+071$ & 71.625 \\
\hline 438.15 & -482.992 & 215.811 & -577.549 & $7.230 \mathrm{E}+068$ & 68.859 \\
\hline 458.15 & -479.064 & 224.579 & -581.955 & $2.267 \mathrm{E}+066$ & 66.355 \\
\hline 473.15 & -476.255 & 230.613 & -585.369 & $4.254 \mathrm{E}+064$ & 64.629 \\
\hline
\end{tabular}

Table 3. Thermodynamic quantities for equation (3) calculated using the HSC Chemistry program (HSC version 6.1)

\begin{tabular}{|c|c|c|c|c|c|}
\hline $\begin{array}{c}\mathrm{T}, \\
\mathrm{K}\end{array}$ & $\begin{array}{c}\Delta \mathrm{H}^{\circ} \mathrm{T}, \\
\mathrm{kJ}\end{array}$ & $\begin{array}{c}\Delta \mathrm{S}^{\circ} \mathrm{T}, \\
\mathrm{J} \mathrm{K}^{-1}\end{array}$ & $\begin{array}{c}\Delta \mathrm{G}^{\circ} \mathrm{T}, \\
\mathrm{kJ} \mathrm{mol}^{-1}\end{array}$ & $\begin{array}{c}\mathrm{K}, \\
\mathrm{mol}^{-1} \mathrm{dm}^{3}\end{array}$ & $\log (\mathrm{K})$ \\
\hline 298.15 & 13.867 & 302.458 & -76.311 & $2.347 \mathrm{E}+013$ & 13.370 \\
\hline 318.15 & 14.150 & 303.375 & -82.368 & $3.346 \mathrm{E}+013$ & 13.525 \\
\hline 338.15 & 14.616 & 304.793 & -88.449 & $4.614 \mathrm{E}+013$ & 13.664 \\
\hline 358.15 & 15.269 & 306.664 & -94.563 & $6.205 \mathrm{E}+013$ & 13.793 \\
\hline 378.15 & 16.547 & 310.133 & -100.730 & $8.226 \mathrm{E}+013$ & 13.915 \\
\hline 398.15 & 19.490 & 317.707 & -107.005 & $1.095 \mathrm{E}+014$ & 14.040 \\
\hline 418.15 & 21.152 & 321.777 & -113.399 & $1.468 \mathrm{E}+014$ & 14.167 \\
\hline 438.15 & 23.383 & 326.981 & -119.883 & $1.965 \mathrm{E}+014$ & 14.293 \\
\hline 458.15 & 26.208 & 333.281 & -126.485 & $2.642 \mathrm{E}+014$ & 14.422 \\
\hline 473.15 & 28.694 & 338.617 & -131.523 & $3.320 \mathrm{E}+014$ & 14.521 \\
\hline
\end{tabular}

From the obtained values of $\Delta \mathrm{G}^{\circ} \mathrm{T}$ it is evident that the probability of reactions (1) - (3) increases with increasing temperature. In nitric acid, ferrous ions are oxidized to ferric ions to form $\mathrm{NO}(\mathrm{g})$ (equation (4)).

$$
\begin{gathered}
3 \mathrm{Fe}^{2+}+\mathrm{NO}_{3}^{-}(\mathrm{a})+4 \mathrm{H}^{+} \rightarrow 3 \mathrm{Fe}^{3+}+ \\
\mathrm{NO}(\mathrm{g})+2 \mathrm{H}_{2} \mathrm{O}
\end{gathered}
$$

Thermodynamic quantities for equation (4) are shown in Table 4. 
In order to prevent leaching of Fe into the solution, oxidative roasting in the temperature range $400-700{ }^{\circ} \mathrm{C}$ is beneficial (equations (5) and (6)):

$$
\begin{gathered}
3 \mathrm{FeS}+5 \mathrm{O}_{2}(\mathrm{~g}) \rightarrow \mathrm{Fe}_{3} \mathrm{O}_{4}+3 \mathrm{SO}_{2}(\mathrm{~g}) \\
4 \mathrm{Fe}_{3} \mathrm{O}_{4}+\mathrm{O}_{2}(\mathrm{~g}) \rightarrow 6 \mathrm{Fe}_{2} \mathrm{O}_{3}
\end{gathered}
$$

The troilite $(\mathrm{FeS})$ in the matte (or other wastes containing $\mathrm{Pb}, \mathrm{Zn}, \mathrm{Cu}$ ) is then transformed into a more stable form as magnetite $\left(\mathrm{Fe}_{3} \mathrm{O}_{4}\right)$. Of course, this causes $\mathrm{SO}_{2}$ and vapours of $\mathrm{As}_{2} \mathrm{O}_{3}$ to get released during the roasting.

Currently, there is a trend to abandon roasting processes that produce emissions and replace them by leaching in an autoclave at temperatures above $120{ }^{\circ} \mathrm{C}$ and higher pressures. Suitable alternative is the pressure oxidation leaching at temperatures in the range
$150-220{ }^{\circ} \mathrm{C}$. $\mathrm{NO}(\mathrm{g})$ released in the pressure vessel during leaching of the waste is oxidizing to $\mathrm{NO}_{2}(\mathrm{~g})$ and subsequently regenerating autocatalytically to $\mathrm{NO}_{2}(\mathrm{aq})$ (equations (7) and (8)).

$$
\begin{gathered}
2 \mathrm{NO}(\mathrm{g})+\mathrm{O}_{2}(\mathrm{~g}) \rightarrow 2 \mathrm{NO}_{2}(\mathrm{~g}) \\
\mathrm{NO}_{2}(\mathrm{~g}) \rightarrow \mathrm{NO}_{2}(\mathrm{aq})
\end{gathered}
$$

Equation (9) describes the oxidation of elemental sulphur formed during the leaching of sulphides in the $\mathrm{HNO}_{3}$ medium (equation (1)) to $\mathrm{H}_{2} \mathrm{SO}_{4}$ during the process.

$$
\mathrm{S}^{0}+2 \mathrm{NO}_{3}^{-}(\mathrm{a}) \rightarrow \mathrm{SO}_{4}^{2-}(\mathrm{a})+2 \mathrm{NO}(\mathrm{a})
$$

Thermodynamic quantities for equation (9) are shown in Table 5.

Table 4. Thermodynamic quantities for equation (4) calculated using the HSC chemistry program (HSC version 6.1)

\begin{tabular}{|c|c|c|c|c|c|}
\hline $\begin{array}{c}\mathrm{T}, \\
\mathrm{K}\end{array}$ & $\begin{array}{c}\Delta \mathrm{H}^{\circ} \mathrm{T}, \\
\mathrm{kJ}\end{array}$ & $\begin{array}{c}\Delta \mathrm{S}^{\circ} \mathrm{T}, \\
\mathrm{J} \mathrm{K}^{-1}\end{array}$ & $\begin{array}{c}\Delta \mathrm{G}^{\circ} \mathrm{T}, \\
\mathrm{kJ} \mathrm{mol}^{-1}\end{array}$ & $\begin{array}{c}\mathrm{K}, \\
\mathrm{mol}^{-1} \mathrm{dm}^{3}\end{array}$ & $\log (\mathrm{K})$ \\
\hline 298.15 & -147.091 & -312.866 & -55.375 & $7.374 \mathrm{E}+009$ & 9.868 \\
\hline 318.15 & -145.955 & -309.055 & -52.265 & $1.015 \mathrm{E}+009$ & 9.006 \\
\hline 338.15 & -144.867 & -305.522 & -49.193 & $1.608 \mathrm{E}+008$ & 8.206 \\
\hline 358.15 & -143.840 & -302.293 & -46.154 & $2.891 \mathrm{E}+007$ & 7.461 \\
\hline 378.15 & -142.879 & -299.363 & -43.146 & $5.826 \mathrm{E}+006$ & 6.765 \\
\hline 398.15 & -141.986 & -296.722 & -40.166 & $1.302 \mathrm{E}+006$ & 6.115 \\
\hline 418.15 & -141.173 & -294.388 & -37.210 & $3.193 \mathrm{E}+005$ & 5.504 \\
\hline 438.15 & -140.449 & -292.364 & -34.277 & $8.525 \mathrm{E}+004$ & 4.931 \\
\hline 458.15 & -139.822 & -290.661 & -31.362 & $2.458 \mathrm{E}+004$ & 4.390 \\
\hline
\end{tabular}

Table 5. Thermodynamic quantities for equation (9) calculated using the HSC chemistry program (HSC version 6.1)

\begin{tabular}{|c|c|c|c|c|c|}
\hline $\begin{array}{c}\mathrm{T}, \\
\mathrm{K}\end{array}$ & $\begin{array}{c}\Delta \mathrm{H}^{\circ} \mathrm{T}, \\
\mathrm{kJ}\end{array}$ & $\begin{array}{c}\Delta \mathrm{S}^{\circ} \mathrm{T}, \\
\mathrm{J} \mathrm{K}^{-1}\end{array}$ & $\begin{array}{c}\Delta \mathrm{G}^{\circ} \mathrm{T}, \\
\mathrm{kJ} \mathrm{mol}^{-1}\end{array}$ & $\begin{array}{c}\mathrm{K}, \\
\mathrm{mol}^{-1} \mathrm{dm}^{3}\end{array}$ & $\log (\mathrm{K})$ \\
\hline 298.15 & -315.379 & 114.364 & -349.477 & $1.706 \mathrm{E}+061$ & 61.232 \\
\hline 318.15 & -317.163 & 108.571 & -351.705 & $5.605 \mathrm{E}+057$ & 57.749 \\
\hline 338.15 & -318.845 & 103.443 & -353.824 & $4.575 \mathrm{E}+054$ & 54.660 \\
\hline 358.15 & -320.536 & 98.585 & -355.844 & $7.993 \mathrm{E}+051$ & 51.903 \\
\hline 378.15 & -322.725 & 92.640 & -357.757 & $2.641 \mathrm{E}+049$ & 49.422 \\
\hline 398.15 & -326.467 & 83.004 & -359.515 & $1.479 \mathrm{E}+047$ & 47.170 \\
\hline 418.15 & -328.820 & 77.242 & -361.119 & $1.301 \mathrm{E}+045$ & 45.114 \\
\hline 438.15 & -331.624 & 70.697 & -362.600 & $1.704 \mathrm{E}+043$ & 43.232 \\
\hline 458.15 & -334.888 & 63.416 & -363.942 & $3.143 \mathrm{E}+041$ & 41.497 \\
\hline
\end{tabular}


The meaning of the other calculated constants can be summarized as the following. If the equilibrium constant $\mathrm{K}$ is $<1$ (or $\log (\mathrm{K})<0$ ) the reaction goes to the left. If the equilibrium constant $\mathrm{K}$ is $>1($ or $\log (\mathrm{K})>0)$ the reaction goes to the right. The value of $\mathrm{K}$ for all calculated reaction equations is over one, ensuring that reactions take place in the direction of products. Negative enthalpy of reaction $\Delta \mathrm{H}^{\circ} \mathrm{T}$ for chemical reactions (1), (2), (4) and (9) means that the reactions are exothermic, positive enthalpy $\Delta \mathrm{H}^{\circ} \mathrm{T}$ of the reaction (3) means that the reaction is endothermic. Entropy changes of the reaction $\Delta \mathrm{S}^{\circ}{ }_{\mathrm{T}}$ (chemical reaction (4)) were negative, and that means that the process was spontaneous and did not require any other chemicals.

Among other things, the autoclave decomposes $\mathrm{Fe}\left(\mathrm{NO}_{3}\right)_{3}$ to form hematite and $\mathrm{NO}(\mathrm{g})$ and a small proportion of $\mathrm{NO}_{2}(\mathrm{~g})$. In a closed system, nitrogen oxide is regenerating to nitric acid. The advantage of a closed system compared to atmospheric leaching is that the regeneration of $\mathrm{HNO}_{3}$ in the autoclave (higher temperatures) allows the use of a lower concentration of acid, and at the same time allows to achieve a higher oxidation-reduction potential. Hydrometallurgical processes allow to reduce or eliminate emissions that would occur in pyrometallurgy or conventional leaching processes without using an autoclave.

\section{CONCLUSION}

Efforts to reduce greenhouse gas emissions and meet the commitments under the Kyoto Protocol (to the 2005 UN Framework Convention on Climate Change) and the 2015 Paris Climate Agreement are forcing EU countries to look for solutions to reduce their carbon footprint and become carbon neutral. Reduction of $\mathrm{SO}_{2}$ and $\mathrm{NO}_{\mathrm{x}}$ emissions in the EU within the last three decades was significant. Between 1990 and 2015, $\mathrm{SO}_{\mathrm{x}}$ emissions in the $\mathrm{EU}$ and $\mathrm{NO}_{\mathrm{x}}$ emissions decreased by $89 \%$. The energy sector remains a problem, in which new ones have not replaced old technologies due to financial demands, and therefore the production of emissions in 2020 is still not close to zero. $\mathrm{SO}_{2}$ and $\mathrm{NO}_{\mathrm{x}}$ emissions are also produced in the metallurgical industry. The most common sources are pyrometallurgical operations of roasting and melting of sulphidic and sulphurcontaining raw materials (e.g., reducing agents). However, a potential source of these emissions can also be the hydrometallurgical recovery of $\mathrm{Pb}$ from intermediates obtained by melting $\mathrm{Pb}$ accumulators, i.e., from $\mathrm{Pb}$ matte and slag. The thermodynamic calculations performed in this work for the individual reactions that can take place in the leaching of galena or magnetite with nitric acid show that the production of gaseous $\mathrm{NO}_{\mathrm{x}}$ is spontaneous. Therefore, it is necessary to look for effective modifications of technologies or new methods of processing $\mathrm{Pb}$ matte or slag. One possibility is to replace atmospheric leaching of $\mathrm{Pb}$ matte in $\mathrm{HNO}_{3}$, which produces gaseous $\mathrm{NO}_{\mathrm{x}}$, by autoclave leaching. With this change, it is possible to achieve the desired selective leaching of lead from iron, to prevent the production of $\mathrm{NO}_{\mathrm{x}}$ emissions and also to reduce the consumption of leaching agent $\left(\mathrm{HNO}_{3}\right)$. The technology provides the possibility to omit the oxidative roasting step, which is undesirable for high energy demands and the production of $\mathrm{SO}_{2}(\mathrm{~g})$.

\section{REFERENCES}

[1] J. Ye, J. Shang, Q. Li, W. Xu, J. Liu, X. Feng, T. Zhu, The use of vacuum ultraviolet irradiation to oxidize $\mathrm{SO}_{2}$ and $\mathrm{NO}_{x}$ for simultaneous desulfurization and denitrification, Journal of Hazardous Material 271(2014), 89-97.

[2] The European Pollutant Release and Transfer Register, https://prtr.eea.europa.eu/\#/home,

Accessed: April 20, 2020.

[3] https://airindex.eea.europa.eu/, Accessed: April 20, 2020.

[4] The Copernicus Atmosphere Monitoring Service (CAMS), https://www.copernicus.eu/en/services/at mosphere, Accessed: February 10, 2020. 
[5] Greenhouse gas emissions per capita, https://ec.europa.eu/eurostat, Accessed: February 10, 2020.

[6] A. Akcil, H. Ciftci, Metals recovery from multimetal sulphide concentrates $\left(\mathrm{CuFeS}_{2}-\mathrm{PbS}-\mathrm{ZnS}\right)$ : combination of thermal process and pressure leaching, International Journal of Mineral Processing 71(2003) 1-4, 233-246.

[7] L. Zhang, Z. Xu, A review of current progress of recycling technologies for metals from waste electrical and electronic equipment, Journal of Cleaner Production 127(2016), 19-36.

[8] HSC Chemistry, 2007. Chemical Reaction and Equilibrium Software with Extensive Thermochemical Database. ver. 6.1., Outotec Research Oy Piori, Finland.

\section{Acknowledgements}

This work was supported by the Slovak Research and Development Agency under contract No. APVV-14-0591. 